\title{
Indoor air pollution and the lung in low- and medium-income countries
}

\author{
Om P. Kurmi, Kin Bong Hubert Lam and Jon G. Ayres
}

ABSTRACT: Over half the world's population, mostly from developing countries, use solid fuel for domestic purposes and are exposed to very high concentrations of harmful air pollutants with potential health effects such as respiratory problems, cardiovascular problems, infant mortality and ocular problems. The evidence also suggests that, although the total percentage of people using solid fuel is decreasing, the absolute number is currently increasing. Exposure to smoke from solid fuel burning increases the risk of chronic obstructive pulmonary disease (COPD) and lung cancer in adults, and acute lower respiratory tract infection/pneumonia in children. Despite the heterogeneity among studies, the association between COPD and exposure to smoke produced by burning different types of solid fuel is consistent. However, there is strong evidence that while coal burning is a risk factor for lung cancer, exposure to other biomass fuel smoke is less so. There is some evidence that reduction of smoke exposure using improved cooking stoves reduces the risk of COPD and, possibly, acute lower respiratory infection in children, so approaches to reduce biomass smoke exposure are likely to result in reductions in the global burden of respiratory disease.

KEYWORDS: Biomass fuel, indoor air pollution, lung diseases, solid fuel

$\mathbf{T}$ he main activities that contribute significantly to indoor air pollution in low- and middle-income countries are the use of solid fuels for residential energy, active and passive smoking inside the house, oil mists and fumes from cooking, smoke from burning mosquito coils during the summer and incense sticks during religious rituals, and keeping pets and animals in the same dwelling where the individuals live.

Globally, $>3$ billion people, approximately half of the world's population, rely on the use of biomass (wood, crop residues, twigs, shrubs, dried dung and charcoal) and coal, collectively known as solid fuels, to meet their basic domestic energy demands for cooking, lighting and heating $[1,2]$. The proportion is even more staggering in rural parts of Africa, Central and South America, and Asia, being $>90 \%$ [3]. The majority of the solid fuels are burnt in inefficient traditional cooking stoves located in places without adequate ventilation, although in sub-Saharan Africa, burning in the open environment is not uncommon [4,5]. A large variety of harmful substances are released during combustion of solid fuels and remain in the indoor environment at very high levels for a number of hours after cooking and heating has stopped, because of the lack of adequate room ventilation. Most people spend $\sim 90 \%$ of their time indoors, even more in the case of females, children, elderly and those with ill health. Cooking in developing countries is often done by females; and mothers tend to keep their young children, especially infants and toddlers, close by during cooking, therefore placing females and children at risk of both acute and long-term ill health from emissions of solid fuel combustion. The degree of risk is related to the levels of exposure, which, in turn, are determined by a number of factors. For instance, kitchen type and the design of living areas in dwellings in developing countries can increase exposure to indoor air pollutants several-fold through natural (but inadequate) ventilation and lack of flues [6, 7]. Seasonality is also important, as exposures to indoor air pollutants during the winter are several times higher than the rest of

For editorial comments see page 12.

AFFILIATIONS

Institute of Occupational and Environmental Medicine, School of Population and Health Sciences, University of Birmingham, Birmingham, UK.

CORRESPONDENCE

O.P. Kurmi

Institute of Occupational and Environmental Medicine, School of Population and Health Sciences University of Birmingham Birmingham B15 2TT UK E-mail: o.kurmi@bham.ac.uk

Received:

Nov 012011

Accepted after revision: Feb 042012

First published online: May 32012 
the year, as people spend more time gathering around fires to keep warm.

\section{USE OF SOLID FUEL AS HOUSEHOLD ENERGY}

Based on the classification by the United Nations Development Programme, there are 140 developing countries, of which 50 are the least developed countries and 45 are sub-Saharan Africa countries. 31 countries belong to both the least developed countries and sub-Saharan Africa categories. Access to clean energy (e.g. electricity and natural gas) is low in developing countries, but the situation is even worse in the least developed countries and in Sub-Saharan Africa (fig. 1), where $82 \%$ and $89 \%$ of the populations, respectively, rely primarily on solid fuels for domestic purposes, compared with $56 \%$ in developing countries [8]. Variation also exists within these countries. In the least developed countries, as much as $97 \%$ of the rural population have access only to solid fuels, compared with $73 \%$ among urban dwellers. The difference is even more marked in sub-Saharan Africa (95\% versus 58\%) [8]. Most of the solid fuel users do not limit themselves to a single type of fuel but rather combinations of different types depending upon availability. Worldwide, wood is the most common biomass used, although coal is predominantly used in China while dried cow dung is used by a smaller fraction of the rural South Asian populations.

\section{Trends in biomass fuel use}

Although the total population relying primarily on the use of biomass as residential energy will increase from 2.68 billion in 2009 to $\sim 2.77$ billion in 2015, and probably remain at that level until 2030 [9], the proportion of the total population from developing countries will decrease from $54 \%$ in 2009 to $51 \%$ in
2015, with further reductions to $44 \%$ in 2030 . In China, the population relying on biomass fuel is readily on the decline and is estimated to fall to $19 \%$ by 2030 . It is anticipated that this trend will be followed by India after 2020 [9] such that by 2030, just $54 \%$ of the Indian population and $52 \%$ of other Asian countries will be using traditional biomass fuels. Increase in the price of kerosene and bottled gas in the developing countries is one of the main reasons for this slower transition to cleaner fuels. However, the pace of decline in sub-Saharan Africa will be much lower compared with other developing countries.

\section{Factors preventing the use of clean fuel}

The influence on the choice of fuel used is multifactorial, but cost and socioeconomic status appear to be the main drivers (fig. 2). Less well-off households spend most of their income purchasing food and clothes and for medical expenses. Depending upon the availability of biomass fuels and the distance required to travel to acquire these fuels, those living in the least developed countries can spend, on average, $2-3 \mathrm{~h}$ per week collecting biomass, leaving little or insufficient time for education [2] and work, thus making it very difficult for these families to improve their socioeconomic status. In rural areas of developing countries, poor families often receive subsidies on clean fuels. However, many switch back to biomass when they cannot afford even the subsidised fuel, making them reliant on the cheaper but dirtier alternatives. The other important factor is the inavailability of clean fuels in rural areas, because of the lack of a sustainable supply-chain mechanism and/or the necessary infrastructure to deliver clean fuels. Consequently, clean fuel is not available at all or

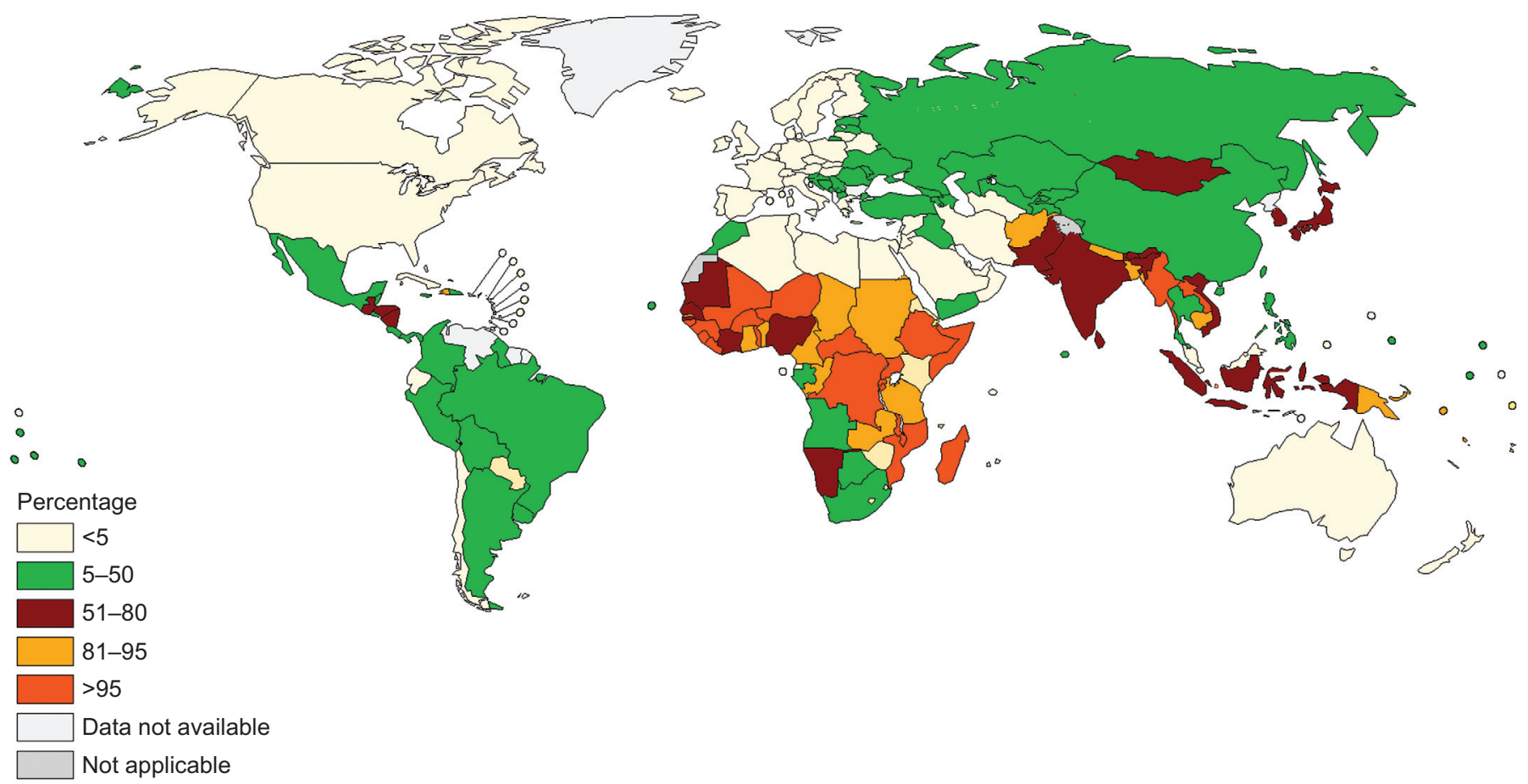

FIGURE 1. Total population using solid fuels in percentage. Modified from [8] with permission from the World Health Organization (WHO). The boundaries used on this map do not imply the expression of any opinion whatsoever on the part of WHO concerning the legal status of any country or territory, or concerning the delimitation of its frontiers or boundaries. 


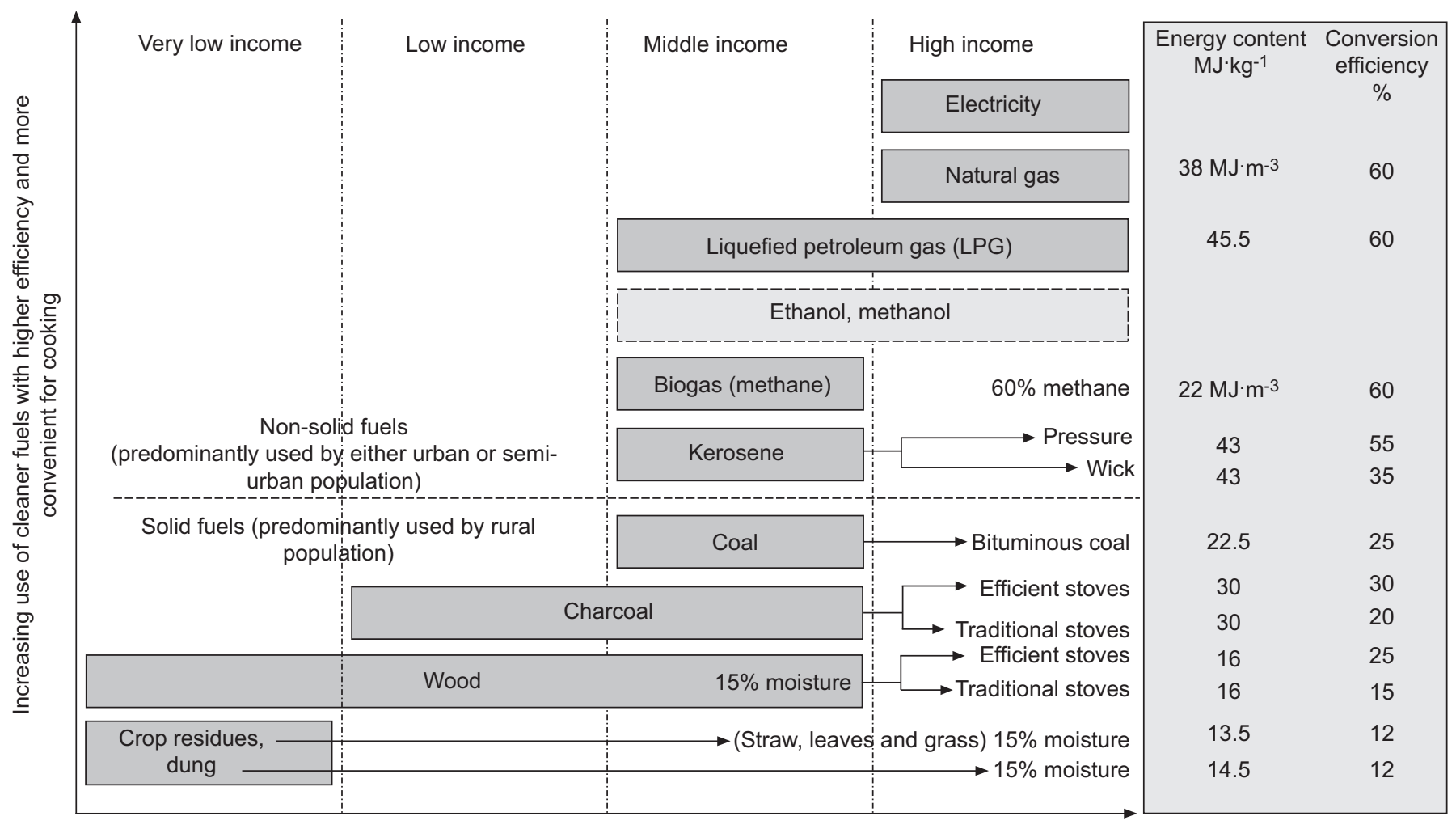

Increasing prosperity and development

FIGURE 2. The energy ladder. Data from $[2,10]$

the demand for clean fuel cannot be met consistently, forcing rural dwellers to continue their dependence on biomass fuels.

\section{Characteristics and toxicity of solid fuel use}

Traditional stoves burning solid fuels have a very low energy conversion efficiency ranging from $12 \%$ to $25 \%$ depending upon the types of fuels (fig. 2). Approximately $8-10 \%$ of the solid fuels undergo partial combustion, often due to inadequate oxygen supply [10]. As a result, one of the main components of biomass smoke is carbon (5-20\% of wood smoke as particulate mass), which is found in the particulate fraction of the smoke and is present across a range of particle sizes. Biomass smoke also contains $>250$ organic compounds, varying mainly by the type of fuel burnt and the combustion conditions [11]. Partial oxidation of organic matter generates high levels of carbon monoxide, as well as hydrogen cyanide, ammonia and nitrogen oxides. In addition, a large number of other toxic and carcinogenic compounds, such as polycyclic aromatic hydrocarbons (PAHs) (e.g. benzo[a]pyrene (BaP)), aldehydes and free radicals [11], have been demonstrated in biomass smoke. While biomass fuels tend to have low levels of halogenated compounds, they may be contaminated by chemicals such as pesticides, or mixed with plastics. Certain varieties of coal, particularly in China, have particularly high fluoride or silica content [12]. Consequently, burning of these specific fuels may lead to production of toxic halogen compounds, such as hydrogen chloride, phosgene, dioxin, chloromethane, bromomethane and other halocarbons [13-15].
The toxicity of biomass smoke has been studied extensively in the laboratory. Rats exposed subchronically to wood smoke at concentrations of $1-10 \mathrm{mg} \cdot \mathrm{m}^{-3}$ over a period of weeks showed reduced carbon monoxide diffusing capacity and increased airway resistance. There were also mild chronic inflammation and squamous metaplasia in the larynx, alveolar macrophage hyperplasia, and slight thickening of the alveolar septa [16]. Wood smoke can cause greater levels of DNA damage in lymphocytes than exposure to liquefied petroleum gas combustion products [17], and can both impair macrophage function and be mutagenic [11].

Wood smoke condensates may damage the lens in rats, causing discolouration and opacities, probably through oxidation by polycyclic aromatic compounds and metal ions [18], while chemicals such as aldehydes and acrolein found in biomass smoke can cause eye irritation.

Biomass smoke is pro-oxidant and burning of biomass fuel may generate high levels of redox-active components. In one study from India, the oxidative potential of particulate matter (PM) from cow dung cake smoke was found to be increased using an in vitro technique involving a synthetic model of the respiratory tract lining fluid [19].

Inadequate combustion of biomass releases carbon monoxide that binds haemoglobin, producing carboxyhaemoglobin, due to the high affinity of haemoglobin for carbon monoxide (200250 times) compared with oxygen [2]. Potentially, this can reduce oxygen transport to key organs and the developing fetus, which may result in low birth weight and perinatal death [20]. 
In humans, acute exposure to sulfur dioxide, which is often released during biomass burning, can increase bronchial reactivity in normal individuals and cause bronchoconstriction in asthmatic individuals at levels of $\sim 100 \mathrm{ppb}$. Longer term exposure may increase susceptibility to viral infections of the lung [21].

A few studies have looked at the toxicity of biomass smoke in exposed populations in developing countries. In chronically biomass smoke-exposed Indian females, activation of circulating platelets, neutrophils and monocytes has been reported with high levels of leukocyte-platelet aggregates [22]. As a number of studies on ambient air pollution suggest that particulate pollutants increase fibrinogen levels, thus enhancing blood coagulation [23], it is plausible that biomass smoke exposure could be a risk factor for cardiovascular events. There have been very few controlled biomass smoke-exposure studies in humans, but there is a suggestion that exposure at levels of $\sim 250 \mu \mathrm{g} \cdot \mathrm{m}^{-3}$ are associated with an increase in circulating factor VIII and serum amyloid A, both of which confer an elevated cardiovascular risk [24].

The inherent toxicity of the smoke from biomass burning differs by the type of fuel, implying differential health risks conferred by different fuels. Airborne endotoxin concentrations in homes burning different types of biomass fuels in Nepal and Malawi [25] have been reported to be higher than those found in occupational settings $[26,27]$ and in the indoor environment in developed countries [28]. The median value of endotoxin (in endotoxin units (EU) per cubic metre) was greatest in households burning maize crop residue $\left(1,609 \mathrm{EU} \cdot \mathrm{m}^{-3}\right)$ followed by cow dung $\left(365 \mathrm{EU} \cdot \mathrm{m}^{-3}\right)$ and wood $\left(113 \mathrm{EU} \cdot \mathrm{m}^{-3}\right)$, all values being much greater than $40 \mathrm{EU} \cdot \mathrm{m}^{-3}$ [29], a health-based guidance limit recommended in the Netherlands for an 8-h time-weighted average occupational exposure.

\section{Improved cooking stoves}

The most effective way of eliminating exposure to smoke from solid fuels is to switch to cleaner fuels, such as electricity, but this option is not always feasible. The most realistic alternative would be to reduce the exposure levels by switching to more efficient, improved cooking stoves. Major projects to produce and disseminate improved cooking stoves in the developing world have been initiated in the last decade. The aims were two-fold. First, by reducing the levels of indoor air pollutants, it was hoped that the health burden would be reduced. Secondly, by improving burning efficiency, fuel use could be economised to help slow down deforestation and desertification. While there is no universal definition, generally speaking, all improved cooking stoves are characterised by a higher efficiency of thermal conversion, a higher heat transfer ratio and a more complete combustion (and therefore a lower emission of smoke and other pollutants) compared with their "traditional" counterparts. Tests (water boiling, kitchen performance and controlled cooking) have been developed and recommended to monitor the performance and efficiency of the improved cooking stoves. Improved cooking stoves can be classified on the basis of: 1) the types of fuel used (operable on single or multiple fuel types), 2) construction materials (made of a single or a combination of materials), 3) portability (fixed or portable) and 4) end-use applications (monofunction for cooking only, or multifunction for cooking, room heating, etc.) [30]. The choice of stove should be customised for the target users, taking into account local cooking requirements, and affordability and availability of fuels. Local availability of construction materials and maintenance are important criteria to long-term self-sustainable projects. In areas where improved cooking stoves are not available, certain modifications of the cooking environment and practices, such as improving ventilation, or even avoiding cooking indoors where possible, could be helpful in reducing the smoke exposure.

At present, $\sim 27 \%$ of the total population using solid fuels (or $38 \%$ of the population in developing countries) have access to improved cooking stoves: more than two-thirds (70\%) in China, $9 \%$ in India and $4 \%$ in other south Asian countries. However, in sub-Saharan Africa and the least developed countries, the figures are as low as $5.8 \%$ and $6.6 \%$, respectively [3].

\section{Exposure monitoring}

Particulate matter

PM is classified on the basis of its aerodynamic diameter (AD), which is a function of particle size, mass and shape. Most of the studies where actual biomass smoke exposures have been measured (as opposed to a simple exposed/unexposed classification) have reported exposures as PM10 (PM with AD $<10 \mu \mathrm{m}$ ), although, more recently, PM2.5 (PM with AD $<2.5 \mu \mathrm{m}$ ) has been used as a PM metric, reflecting the likelihood that greater toxicity resides in the smaller size fraction. PM can be measured either by gravimetric techniques or by photometric devices. Gravimetric techniques give an aggregate of exposure concentrations over a period of time but photometric techniques are gaining popularity as they measure real-time PM concentrations in a repeated manner, which provides information on the variation of particle concentration over time and in relation to different activities. The downside of this technique is that measurements need to be calibrated against gravimetric results in the environment, where exposure monitoring needs to be performed, as the light scattering method often tends to overestimate PM concentrations [31].

Previous work has shown 24-h indoor concentrations of PM10 generated from solid fuels in different settings to be in the range of $300-3,000 \mu \mathrm{g} \cdot \mathrm{m}^{-3}$, with peaks reaching as high as $20,000 \mu \mathrm{g} \cdot \mathrm{m}^{-3}$ during cooking [4, 32-35]. In a wood-using community in Nepal, the 24-h average PM2.5 was found to be $680 \mu \mathrm{g} \cdot \mathrm{m}^{-3}$ (range $616-744 \mu \mathrm{g} \cdot \mathrm{m}^{-3}$ ) [31], which is similar to other studies from Guatemala $\left(22-\mathrm{h}\right.$ average $\left.520 \mu \mathrm{g} \cdot \mathrm{m}^{-3}\right)$ [4] and China (24-h average $\left.489 \mu \mathrm{g} \cdot \mathrm{m}^{-3}\right)$ [36]. All these reported concentrations are several-fold higher than the World Health Organization (WHO) global ambient air quality guidelines, which recommend that the 24-h and annual mean PM10 concentration should not exceed 50 and $20 \mu \mathrm{g} \cdot \mathrm{m}^{-3}$, respectively, with PM2.5 not exceeding 25 and $10 \mu \mathrm{g} \cdot \mathrm{m}^{-3}$, respectively [37]. These results are several-fold higher than results from the UK (12-34 $\mu \mathrm{g} \cdot \mathrm{m}^{-3}$ for PM10) [38] and USA $\left(\leqslant 35 \mu \mathrm{g} \cdot \mathrm{m}^{-3}\right.$ for total suspended dust) [39].

\section{Carbon monoxide}

Carbon monoxide has been suggested as a cheaper but surrogate measure of indoor air pollution caused by burning biomass fuel. Carbon dioxide is measured by using either colour-changing diffusion tubes or electrochemical monitors. 
Diffusion tubes can only measure total exposure over time and the carbon monoxide concentration is indicated by the stain inside the tubes when in contact with carbon monoxide. More recently, small electrochemical devices (e.g. $\mathrm{HOBO}_{\circledast}$ Data Logger (Onset ${ }_{\circledR}$, Cape Cod, MA, USA) and EL-USB-CO Data Logger (Lascar Electronics, Salisbury, UK)) have been used to measure carbon monoxide concentrations. These devices are cheaper, smaller and require less power to operate over extended time periods than diffusion tubes.

BRUCE et al. [40] reported 24-h carbon monoxide concentration in homes using an improved stove of just over 3 ppm, compared with 12.4 ppm with open fires, while our own work in Nepal found broadly similar levels (18 ppm) but with substantial increases to around $200 \mathrm{ppm}$ during cooking (unpublished observations), while results from Guatemala (average $5.9 \mathrm{ppm}$ ) were similar [4]. The concentration of carbon monoxide will depend upon the efficiency of fuel combustion and the moisture content of the fuel [41], wet wood fuel generates more smoke, and thus more carbon monoxide, due to incomplete oxidation of the carbon content. WHO recommended time-weighted average guidelines for carbon monoxide are $87 \mathrm{ppm}\left(100 \mathrm{mg} \cdot \mathrm{m}^{-3}\right)$ for $15 \mathrm{~min}, 52 \mathrm{ppm}$ $\left(60 \mathrm{mg} \cdot \mathrm{m}^{-3}\right)$ for $30 \mathrm{~min}, 26 \mathrm{ppm}\left(30 \mathrm{mg} \cdot \mathrm{m}^{-3}\right)$ for $1 \mathrm{~h}$ and $9 \mathrm{ppm}$ $\left(10 \mathrm{mg} \cdot \mathrm{m}^{-3}\right)$ for $8 \mathrm{~h} \mathrm{[42].}$

\section{HEALTH EFFECTS FROM EXPOSURE TO SOLID FUEL SMOKE}

It is estimated that 1.9 million people die prematurely due to exposure to smoke from solid fuel burning [43]. According to $\mathrm{WHO}$, exposure to smoke from solid fuel burning is ranked as the top environmental risk factor worldwide, being responsible for $3.3 \%$ of all mortality and $2.7 \%$ of all disability-adjusted lifeyears per year [44]. Long-term exposure to solid fuel smoke is clearly associated with chronic obstructive pulmonary disease (COPD), increased risk of acute respiratory infections/pneumonia, lung cancer, tuberculosis (TB) and cataracts [45-51]. The evidence is weaker for end-points such as asthma, adverse pregnancy outcomes, cancer of the upper aerodigestive tract, interstitial lung disease and ischaemic heart disease. More research, both from animal and human studies, is needed to establish the causal association between these health effects and exposure to biomass smoke. Some of the health effects associated with solid-fuel smoke exposure are acute, and include oxygen desaturation [52] and acute lower respiratory infection (ALRI)/pneumonia [53].

Here we discuss in detail the respiratory health effects associated with smoke from solid-fuel burning.

The epidemiological data on biomass use from Asia (most of them from south Asia), sub-Saharan Africa, and central and south America have provided substantial evidence to suggest that there is an association between exposure to biomass smoke and COPD in adults, and ALRI/pneumonia in children.

\section{Chronic obstructive pulmonary disease}

COPD, once regarded as a disease of developed countries, is now recognised as a common disease in developing countries. COPD is the fourth leading cause of all deaths: $\sim 3$ million people died from the condition in 2004, of whom $90 \%$ were from low- and middle-income countries [54]. While the main contributing factors to COPD in developed countries are cigarette smoke and occupational causes, exposure to solid fuel smoke is a major contributing factor in developing countries. According to WHO estimates, $\sim 700,000$ out of the 2.7 million global deaths due to COPD could be attributable to indoor air pollution from solid fuels [55], particularly in females. However, the purported link between exposure to solid fuel smoke and COPD has often been based on surrogate measures of exposure and no studies have shown a relationship between direct measurement of biomass smoke exposure and the incidence or prevalence of COPD. Lower socioeconomic status increases the risk of developing COPD, although which component factors (e.g. poor housing, poor nutrition, low income and no/poor education) are the most important in influencing COPD and to what extent is unclear. Nevertheless, one indicator of low socioeconomic status, the use of solid fuel, has been suggested as a key causal factor [56-58]. Although the underlying mechanisms for the development of COPD among nonsmokers exposed to biomass fuels are still unknown, some human challenge [59] and toxicological studies [19, 60] have reported that biomass burning produces chemicals with high oxidative potential, and have implicated that oxidative stress and DNA damage are underlying mechanisms responsible for the pathogenesis of COPD [61, 62] in those exposed to biomass smoke. RIVERA et al. [63] compared the lung morphology in COPD secondary to cigarette and biomass smoke, and reported that smokers with COPD had a larger extent of emphysema and goblet cell metaplasia than females exposed to biomass smoke, but the latter presented more local scarring and pigment deposition in the lung parenchyma, and more fibrosis in the small airways. In contrast, MORAN-MENDOZA et al. [64] found that wood smoke-exposed, nonsmoking females had histopathological findings (dyspnoea, airway obstruction, air trapping, increased airway resistance, pathological evidence of anthracosis, chronic bronchitis, centrilobular emphysema, bronchial squamous metaplasia and pulmonary hypertension) similar to smokers.

Studies on solid fuel use and COPD are often observational, small in sample size with insufficient statistical power to show a clear relationship, and have relevant confounding factors that are often inadequately addressed. A further issue is the use of nonstandard definitions of COPD or chronic bronchitis. Therefore, the findings across studies should be viewed with some caution, as the published estimates may be either underor overestimates of the true burden. A systematic review and meta-analysis [45] identified 23 studies, 10 reporting COPD based on both physician diagnosis and spirometric definitions, 11 reporting chronic bronchitis based on respiratory questionnaire data, and two reporting both COPD and chronic bronchitis. The pooled effect estimate for lung function diagnosed COPD (OR 2.96, 95\% CI 2.01-4.37) was greater than those diagnosed by a doctor in hospital (OR 2.29, 95\% CI 0.70$7.52)$, with a combined pooled effect estimate of $2.80(95 \% \mathrm{CI}$ 1.85-4.23) for COPD (fig. 3). Similarly, the pooled effect estimate for chronic bronchitis (fig. 4) was 2.32 (95\% CI 1.92-2.80). The findings, published in 2010 [45], are similar to a recent metaanalysis [87] published for both chronic bronchitis (OR 2.52, 95\% CI 1.88-3.38) and COPD (OR 2.40, 95\% CI 1.47-3.93).

It is likely that exposure to biomass smoke from an early age will be important in retarding lung growth. In a study from 


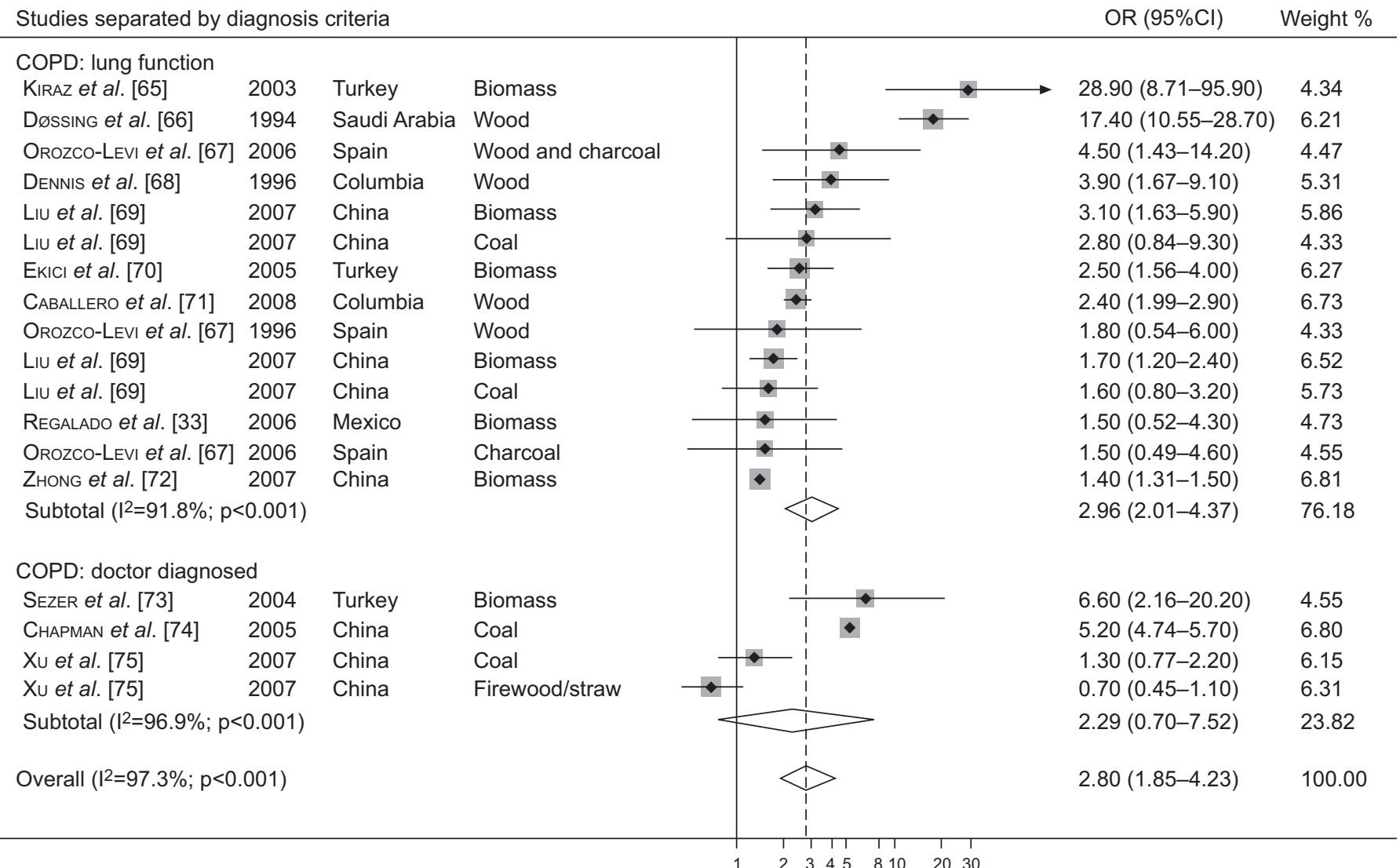

Log of odds ratio

FIGURE 3. Forest plot showing risk of chronic obstructive pulmonary disease (COPD) in populations exposed to solid fuel smoke. Reproduced from [45] with permission from the publisher.

Nepal where lung function was compared between a biomass smoke-exposed population and an unexposed population [88], the absolute values for various indices of lung function were significantly lower in both males and females in the biomass smoke-exposed group, the difference being evident even in the youngest age group studied (16-25 yrs). This suggests an effect of biomass smoke exposure on lung growth in addition to any effect on rate of decline of lung function in later years. The prevalence of airflow obstruction (defined as forced expiratory volume in $1 \mathrm{~s} /$ forced vital capacity ratio $<0.70$ ) in the biomass smoke-exposed group was almost doubled compared with the unexposed ( $20 \%$ versus $11 \%)$.

Overall, there is good evidence that exposure to biomass smoke is associated with airflow obstruction and an at least doubling of the risk of COPD, the effect being detected by young adulthood.

\section{Asthma}

There is a wide variation in the prevalence of asthma worldwide [89]. Asthma has been less widely studied in developing countries compared with developed countries, and understanding of the very different set of risk factors in these countries associated with its development, notably indoor environment and lifestyle, is limited. There is evidence that growing up in an agricultural environment is associated with a reduced risk of developing asthma, perhaps mediated by exposure to endotoxin [90], so it might be expected that exposure to biomass, which largely occurs in rural communities, might not be associated with development of asthma per se, but could be associated with exacerbations of existing asthma or with respiratory symptoms that might lead to a mistaken diagnosis of asthma. Some studies in developing countries have considered possible associations with biomass / solid fuel pollutant exposures [91-93]. SAMUELSEN et al. [94] studied allergy adjuvant effect of particles from wood smoke and road traffic in laboratory animals, and found that particles generated from wood burning had about the same capacity to enhance allergic sensitisation as road traffic particles, but less than diesel exhaust particles. Acute exposure to biomass smoke causes bronchial irritation, inflammation and increases bronchial reactivity that is possibly responsible for exacerbation of asthma [20].

Published effect sizes for asthma in relation to biomass exposure are presented in table 1. All these studies adopted different techniques to determine asthma and none measured actual biomass exposure levels. While this limits the ability to compare the studies, all show positive associations between indoor air pollution and asthma, at least in children. 


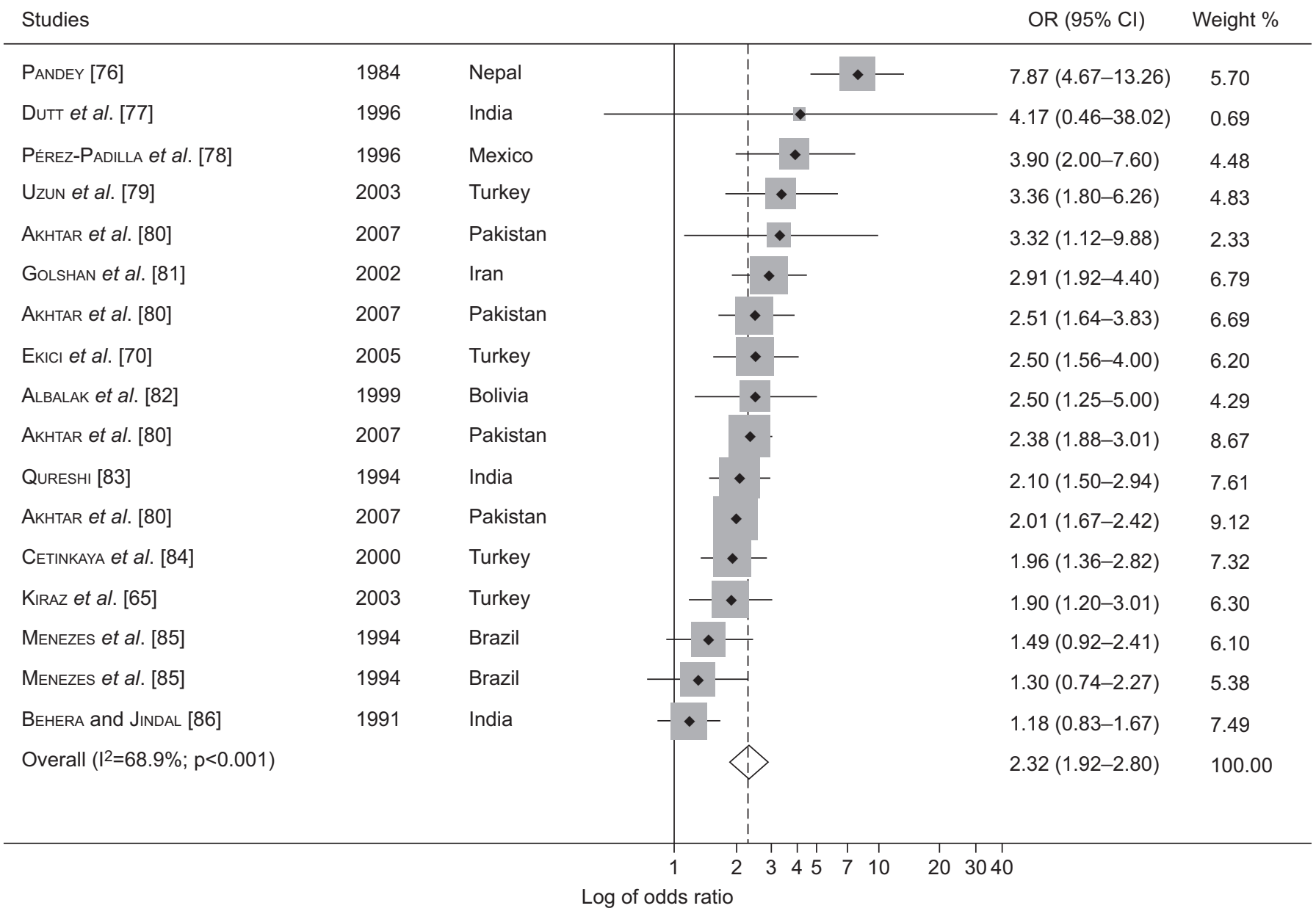

FIGURE 4. Forest plot showing risk of chronic bronchitis in populations exposed to solid fuel smoke. Reproduced from [45] with permission from the publisher.

A case-control study in Nepal assessed the home environment of schoolchildren in relation to asthma, using the International Study of Asthma and Allergies in Childhood questionnaire, and found that passive smoking and use of biomass fuels was separately associated with an increased risk of asthma in males only, but keeping animals in the home was associated with a lower risk of asthma (OR 0.2, 95\% CI 0.1-0.5) [97]. This finding is supported by a similar case-control study from Kenya [95], which found that dampness in the child's sleeping area, indoor air pollution and presence of rugs or carpets in the child's bedroom were strongly associated with asthma (OR 2.0-4.9), and by a study from Guatemala in relation to asthma symptoms in 4-6-yr-old children [89]. In contrast, a study from Malaysia only found an association of asthma with environmental tobacco smoke (ETS) and exposure to mosquito coil smoke [96].

A meta-analysis of these four studies showed that exposure to indoor air pollution approximately doubles the risk of developing asthma in children (OR 1.96, 95\% CI 1.29-2.99) but some caution needs to be taken in interpretation, as the methodology was imperfect in some way in all studies.

Only one study has considered biomass smoke exposure and asthma in adults [89]. Using a simple approach to defining asthma (a positive response by the head of household to the question "Does anyone listed suffer from asthma?"), the study found that people living in houses using biomass as a domestic fuel and who were active smokers had a significantly higher risk of asthma. Although this study found that asthma in elderly males and females ( $\geqslant 60 \mathrm{yrs}$ ) is associated with use of biomass fuel, the exposure was based on a crude yes/no response and there is a high possibility of misclassifying asthma.

In summary, the evidence possibly supports a role for biomass exposure being causally related to asthma in children, but formal, well-designed studies are needed to confirm this possibility. In particular, methods should ensure as tight a diagnosis of asthma as possible (perhaps including measures of bronchial reactivity, e.g. using mannitol challenge or exercise) to determine whether these findings simply reflect a pattern of asthma-like symptoms or true asthma.

\section{Acute respiratory infection}

Acute respiratory infection (ARI) can be divided into two types, upper respiratory tract infections (URTIs) and lower respiratory tract infections (LRTIs), which can, in turn, be categorised on clinical conditions, aetiology and markers of severity [58]. Although there are clinical and epidemiological criteria to separate URTI from LRTI worldwide, there are no uniformly accepted definitions used in epidemiological 


\begin{tabular}{|c|c|c|c|c|c|c|}
\hline $\begin{array}{l}\text { First author } \\
\text { [ref.] }\end{array}$ & Country & Fuel type & Sample size & Sample type & Diagnosis criteria & $\begin{array}{l}\text { Effect size } \\
\text { OR }(95 \% \mathrm{Cl})\end{array}$ \\
\hline МоHAMED [95] & Kenya & $\begin{array}{l}\text { Biomass and } \\
\text { clean fuel }\end{array}$ & $\begin{array}{c}77 \text { cases and } 77 \\
\text { controls }\end{array}$ & $\begin{array}{l}\text { Children aged } \\
\text { 9-11 yrs }\end{array}$ & Adapted from IUATLD & $2.5(2.0-6.4)$ \\
\hline Azızı [96] & Malaysia & Wood and kerosene & $\begin{array}{l}158 \text { cases and } \\
201 \text { control }\end{array}$ & $\begin{array}{l}\text { Children aged } \\
1 \text { month to } 5 \text { yrs }\end{array}$ & $\begin{array}{l}\text { Hospital-based doctor } \\
\text { diagnosed }\end{array}$ & $\begin{array}{l}1.4(0.60-3.60) \text { wood and } \\
0.9(0.50-1.60) \text { kerosene }\end{array}$ \\
\hline MeLSom [97] & Nepal & $\begin{array}{l}\text { Biomass and } \\
\text { clean fuel }\end{array}$ & $\begin{array}{l}121 \text { cases and } \\
126 \text { control }\end{array}$ & $\begin{array}{l}\text { Children aged } \\
11-17 \text { yrs }\end{array}$ & ISAAC criteria & $2.2(1.0-4.5)$ \\
\hline MISHRA [98] & India & $\begin{array}{l}\text { Biomass and } \\
\text { clean fuel }\end{array}$ & 38595 subjects & $\begin{array}{l}\text { Adults aged } \\
\geqslant 60 \mathrm{yrs}\end{array}$ & $\begin{array}{l}\text { Based on interviewee replying } \\
\text { yes to asthma questionnaire }\end{array}$ & $1.59(1.30-1.94)$ \\
\hline SChEI [99] & Guatemala & Wood & 1058 subjects & Children aged $4-6$ yrs & ISAAC criteria & $1.8(0.76-4.19)$ \\
\hline
\end{tabular}

IUALTD: International Union Against Tuberculosis and Lung Disease; ISAAC: International Study of Asthma and Allergies in Childhood.

research. The lack of a uniformly accepted definition of ARI may cause bias that would contribute to the heterogeneity in reporting across different studies. The possible mechanism related to respiratory infection from acute exposure to PM from biomass burning might be due to reduced mucociliary clearance, and long-term exposure increasing susceptibility to bacterial and viral lung infections [20].

LRTIs are major causes of morbidity and mortality, leading to $>4$ million deaths per year worldwide, $\sim 69 \%$ of which occur in developing countries [100,101]. After neonatal deaths, ARI $(17 \%)$ is the second leading cause of deaths in children $<5$ yrs of age and the fourth leading cause of death in the world, where $7.4 \%$ of females and $7.1 \%$ of males die annually due to respiratory infections [101]. In low-income countries, respiratory infection is the leading cause of deaths (2.94 million, $11.2 \%$ ) [101].

Mortality due to respiratory infection is higher in the $<5$ and $\geqslant 60 \mathrm{yrs}$ age groups. Young children exposed to solid fuel smoke have two to three times more risk of serious ARI than unexposed children [58]. Deaths due to respiratory diseases are highest in African countries followed by eastern Mediterranean and then south-east Asian countries [101], where most of the people are of low socioeconomic status. In these areas, $>70 \%$ of the population use solid fuels for domestic purposes and respiratory deaths from respiratory tract infections could well be attributed to the high exposure from the burning of biomass / solid fuel. Exposure to air pollutants might increase the incidence of ARI by adversely affecting specific and nonspecific defences of the respiratory tract against pathogens [102]. It is important to emphasise that death due to ARI is mainly associated with LRTI rather than URTI.

A longitudinal study in rural Kenya studied ARI and acute LRTI (ALRI) in children under the age of 5 yrs [5, 103]. The study measured biomass exposure as PM10 and found a dose-response relationship between PM10 and the increase in ARI and ALRI frequency. The rates of ARI and ALRI were higher for exposures of PM10 below $1,000-2,000 \mu \mathrm{g} \cdot \mathrm{m}^{-3}$ but the rate of increase declined where exposure concentrations were $>2,000 \mu \mathrm{g} \cdot \mathrm{m}^{-3}$.

A longitudinal study (1984-1985) in Nepal of children $<2$ yrs of age showed a possible relationship between ARI and average number of hours spent in the kitchen (OR 2.2) reported by the mother [104]. A suggestion of a dose-response relationship was found in this study but the exposure assessment was not validated.

A case-control study from urban Nigeria did not find significant associations between age, nutritional status, ETS exposure, location of cooking and crowding with ALRI [105]. MisHRA [106] studied acute respiratory infection in preschool children ( $<5$ yrs of age) in Zimbabwe and found that $\sim 16 \%$ of the children had ARI at the time of their survey. The study reported that, after adjusting for appropriate confounders, children in households using biomass were more than twice (OR 2.2) as likely to suffer from ARI as children from households using clean fuel for domestic purposes. A 1-yr cohort study carried out in 500 Gambian children $<5$ yrs of age reported that parental smoking appeared (nonsignificantly) to increase the risk of ALRI [107]. However, the risk of ALRI was six times higher in females than in males, perhaps due to the fact that females are carried on their mother's back more often than boys during cooking and, hence, are exposed more to biomass exposure.

A meta-analysis of 24 studies relating to pneumonia in children $<5$ yrs of age who were exposed to smoke from solid fuels showed the exposure to solid fuel smoke approximately doubles the risk of pneumonia (OR 1.78, 95\% CI 1.45-2.18) [108]. There is thus consistent evidence that biomass smoke exposure is associated with an increased risk of ARI/ pneumonia in children.

\section{Tuberculosis}

There is inconsistent evidence that exposure to biomass smoke increases the risk of TB $[109,110]$. The proposed mechanism is that biomass smoke compromises the respiratory system's ability to resist infection by Mycobacterium tuberculosis or to resist development of active TB in already infected persons [111]. There is enough evidence to support the belief that current and/or former smoking is associated with TB [110, 112116] and some evidence to suggest that passive smoking is also a risk factor [117, 118] acting via a range of potential immune mechanisms. Similarly, biomass exposure interferes with mucociliary clearance [119] and decreases several antibacterial 
properties of lung macrophages, such as adherence and phagocytic rate [120,121], providing theoretical mechanistic reasons to support the possibility that biomass smoke might be a risk factor for TB.

The available data suggest (table 2) that there might be a causal link between exposure to biomass smoke and either an increased risk of acquiring TB or progression of TB to clinical disease. There are very few studies that have explored this link, and there is heterogeneity in design, measurement of outcome and the magnitude of risk estimates, which need to be explored further to come to a firm conclusion. Most of the studies related to biomass use and TB suggest that prevalence of TB is higher in communities with poor sanitation and lower socioeconomic status, and these communities primarily use solid fuel for domestic purposes. A meta-analysis on the 10 studies mentioned in table 2 revealed a pooled effect estimate (OR 1.55, 95\% CI 1.11-2.18) suggesting that individuals exposed to solid fuel smoke are 55\% more likely to get TB than an unexposed group. While there was significant heterogeneity among the studies $\left(\mathrm{I}^{2} 70 \%, \mathrm{p}<0.001\right)$, no significant publication bias was reported.

\section{Lung cancer}

Lung cancer is one of the leading causes of death, accounting for 1.3 million deaths annually worldwide [129]. While smoking is the major risk factor, as many as a quarter of cases are not attributable to tobacco use [130]. Lung cancer in neversmokers is more common in females than males, although there is considerable regional variation in the proportions of nonsmoking females with lung cancer; for instance, in east and south Asia, up to $83 \%$ of female lung cancer cases are neversmokers, compared with $15 \%$ in the USA [130]. Emissions from combustion of solid fuels have been shown to have high concentrations of PAHs, $\mathrm{BaP}$ and PM2.5, which in turn have been associated with high lung cancer rates [130].

A meta-analysis of 28 studies relating to lung cancer in subjects exposed to solid fuel smoke showed a greater effect of coal smoke on lung cancer rates (OR 1.82, 95\% CI 1.60-2.06) with biomass smoke, predominantly wood (OR 1.50, 95\% CI 1.171.94) and mixed biomass fuel smoke (OR 1.13, 95\% CI 0.52 2.46), showing lesser effects. The higher risk of lung cancer in coal users was not surprising as combustion products obtained from in-home coal burning contain a range of PAHs classified as group 1 carcinogens [131]. The general mechanism emerging from the study of $\mathrm{PAHs}$ such as $\mathrm{BaP}$ is genotoxicity, where $\mathrm{BaP}$ is metabolised to an electrophilic form that adducts DNA. The International Agency for Research on Cancer (IARC) has classified combustion products from biomass (primarily wood) use as probably carcinogenic to humans (group 2A) for lung cancer due to "limited evidence" in humans and experimental animals [131].

TABLE 2 Studies of tuberculosis infections in relation to biomass exposure

\begin{tabular}{|c|c|c|c|}
\hline Country & Fuel type & Sample size & Sample type \\
\hline
\end{tabular}

\begin{tabular}{|c|c|c|c|c|c|}
\hline \multicolumn{6}{|l|}{ Case-control studies } \\
\hline GNINAFON et al. [122] & Benin & Solid fuel & $\begin{array}{l}200 \text { cases and } \\
400 \text { controls }\end{array}$ & $\begin{array}{l}\text { Age- and sex-matched, } \\
\text { community-based } \\
\text { controls }\end{array}$ & $1.7(1.1-2.8)$ \\
\hline KAN et al. [123] & China & Solid fuel & $\begin{array}{l}202 \text { cases and } \\
404 \text { controls }\end{array}$ & $\begin{array}{l}\text { Age- and sex-matched, } \\
\text { community-based } \\
\text { controls }\end{array}$ & $1.08(0.62-1.87)^{\#}$ \\
\hline LAKSHMI et al. [124] & India & Biomass & $\begin{array}{l}126 \text { cases and } \\
252 \text { controls }\end{array}$ & $\begin{array}{l}\text { Age-matched, community- } \\
\text { based controls }\end{array}$ & $3.14(1.15-8.56)^{\bullet}$ \\
\hline KOLAPPAN et al. [125] & India & Biomass & $\begin{array}{l}255 \text { cases and } \\
1275 \text { controls }\end{array}$ & $\begin{array}{l}\text { Age- and sex-matched, } \\
\text { community-based } \\
\text { controls }\end{array}$ & $1.7(1.0-2.9)^{+}$ \\
\hline POKHREL et al. [109] & Nepal & $\begin{array}{l}\text { Biomass and } \\
\text { kerosene }\end{array}$ & $\begin{array}{l}125 \text { cases and } \\
250 \text { controls }\end{array}$ & $\begin{array}{l}\text { Age-matched, hospital- } \\
\text { based controls }\end{array}$ & $\begin{array}{l}1.21(0.48-3.05) \text { biomass and } \\
3.36(1.01-11.22) \text { kerosene }\end{array}$ \\
\hline SHETTY et al. [113] & India & Biomass & $\begin{array}{l}189 \text { cases and } \\
189 \text { controls }\end{array}$ & $\begin{array}{l}\text { Matched, hospital- } \\
\text { based controls }\end{array}$ & $0.90(0.46-1.76)^{\#}$ \\
\hline CRAMPIN et al. [110] & Malawi & Biomass & $\begin{array}{l}598 \text { cases and } \\
992 \text { controls }\end{array}$ & $\begin{array}{l}\text { Community-based } \\
\text { controls }\end{array}$ & $0.60(0.3-1.1)^{\#}$ \\
\hline PEREZ-PADILLA et al. [126] & Mexico & $\begin{array}{c}\text { Biomass (present/ } \\
\text { past) }\end{array}$ & $\begin{array}{l}288 \text { cases and } \\
545 \text { controls }\end{array}$ & $\begin{array}{l}\text { Hospital-based } \\
\text { controls }\end{array}$ & $\begin{array}{l}2.2(1.1-4.2) \text { present, } 1.5 \\
(1.0-2.40) \text { present or past } \\
\text { and } 1.1(0.6-2.0) \text { past }\end{array}$ \\
\hline \multicolumn{6}{|l|}{ Cross-sectional studies } \\
\hline MisHRA et al. [127] & India & Biomass & $\begin{array}{l}260162 \text { persons } \\
\text { screened }\end{array}$ & $\begin{array}{l}\text { All aged } \geqslant 20 \text { yrs in } \\
\text { the sampling location }\end{array}$ & $2.58(1.98-3.37)$ \\
\hline GUPTA et al. [128] & India & Biomass & 707 & Adults & $2.54(1.07-6.04)$ \\
\hline
\end{tabular}

${ }^{\#}$ : nonsignificant; ${ }^{\bullet}: p=0.02 ;{ }^{+}: p=0.04$ 
One methodological issue in such analyses is the use of appropriate comparison populations. The pooled effect size obtained from studies using population-based controls (carrying 56\% weight) (OR 1.83, 95\% CI 1.51-2.21) were greater than those using hospital-based controls (39\% weight) (OR 1.63, $95 \%$ CI 1.34-1.97). This suggests the evidence of the carcinogenicity of biomass smoke is still not conclusive, supporting the IARC evaluation.

Cigarette smoking has been widely identified as the main contributory factor for lung cancer worldwide [132, 133] but no objective measurement of smoking was carried out in any of the studies included here. However, all studies included in this review either adjusted for smoking or studied a population of nonsmokers. While it is accepted that self-reported smoking history is the best that can be achieved when considering life-long smoking details, objective measurement of smoking, such as salivary cotinine, is becoming more easily usable in field studies and, at least, provides information on current smoking and will help reduce exposure misclassification slightly.

Almost $75 \%$ of the studies included in this meta-analysis did not adjust for ETS but studies dealing with coal smoke exposure with ETS adjusted (OR 1.47, 95\% CI 1.13-1.91) had lower pooled effect sizes compared to those where ETS was not adjusted for (OR 1.74, 95\% CI 1.60-1.89). Only one study out of eight related to biomass smoke exposure adjusted for ETS and had an effect size higher than the others that were not adjusted for ETS. Thus, ambiguity regarding the combined effect of smoking, combustion products of solid fuel and ETS exposure still prevails and future studies need to address this issue. There is evidence from occupational studies that smoking and some occupational exposures (e.g. asbestos and PAHs) have a multiplicative, rather than simply an additive, effect on lung cancer risk [134, 135], and it is therefore possible that such a potentiating effect may be seen with respect to smoke from solid fuel burning, especially that from coal.

Most of the cooking in developing countries is done by females, who are therefore more likely to be exposed to indoor air pollution than males. The pooled effect size shows that the risk of lung cancer is greater in females (OR 1.81, 95\% CI 1.542.12) compared with males (OR 1.16, 95\% CI 0.79-1.69), similar to that reported in a limited earlier meta-analysis for females only (OR 1.83, 95\% CI 0.62-5.41) [136].

There may be an effect on cell type, as the pooled effect size for squamous cell carcinoma was greatest (OR 3.58, 95\% CI 1.588.12) followed by adenocarcinoma (OR 2.33, 95\% CI 1.72-3.17) and unspecified lung cancer type (OR 1.57, 95\% CI 1.38-1.80). Squamous cell lung cancer is more commonly associated with cigarette smoking [137], although reported series of lung cancers have recently shown an increase in the proportion of adenocarcinomas, which is thought not to be simply an issue of changes in classification/grading [138].

\section{INDOOR AIR POLLUTION FROM OTHER SOURCES AND ASSOCIATED HEALTH EFFECTS}

There are number of other sources that contribute to the worsening of indoor air pollution in developing countries and may thus contribute to ill health.

\section{Cooking oil fumes}

Cooking emissions

Cooking is the treatment of food with heat. High temperature initiates volatilisation as well as a number of chemical reactions in the food ingredients, generally involving decomposition of lipids and amino acids [139]. The resulting emissions have been found to contain PM [140], volatile organic compounds (VOCs) [141] and other organic compounds, including PAHs [142] and heterocyclic amines [143], some of which are potent mutagens and carcinogens. The types and levels of pollutants in cooking emissions are highly heterogeneous and depend on food ingredients [144, 145]. For example, beef steak fried with margarine generated significantly higher levels of PM and aldehydes than when rapeseed oil, olive oil or soybean oil was used under the same cooking procedures [144]. However, CHIANG and co-workers [146, 147] analysed emission samples in Taiwan and reported nonsignificant variations of levels of PAHs and aromatic amines using different types of cooking oil. In a controlled environment, FULLANA et al. [145] reported higher levels of acetaldehyde and acrolein emissions from heated canola oil and olive oil, and suggested this might be related to their difference in fatty acid composition, where canola oil contains a higher proportion of linolenic acid and a small proportion of oleic acid than that in olive oil. The same report also provided evidence that the levels of pollutants are positively correlated with heating time and temperature [145]. Not surprisingly, different methods of cooking, such as frying (pan, stir and deep frying), grilling and baking, can affect the levels of emission. For instance, when stir frying meat, the concentration of $\mathrm{BaP}\left(2.64 \mu \mathrm{g}\right.$ per $\left.100 \mathrm{~m}^{3}\right)$ can be four times as high as that when it was boiled $(0.65 \mu \mathrm{g}$ per $100 \mathrm{~m}^{3}$ ) [148].

Chinese cooking appears to be of particular concern because the techniques involved generally require high temperature cooking with oil, such as in stir frying and deep frying. This is supported by a study in Taiwan, which found the annual rate of PAH emission was highest from Chinese restaurants compared with Western, fast food and Japanese restaurants, after taking into account a number of factors including cooking oil consumption and cooking methods [149]. A study in Singapore compared the concentrations of PM2.5 and PAHs in three ethnic food stalls and found the levels of both pollutants to be highest in Malay, followed by Chinese and Indian stalls. The difference in the levels could be explained by the frying processes predominantly used at the Malay (deep frying) and the Chinese (stir frying) stalls, whereas simmering (at lower temperature) was mostly used at the Indian stall [150].

\section{Respiratory effects}

Compared with the wealth of knowledge on the respiratory effects of biomass and solid fuels, far fewer studies have been dedicated to cooking-related emissions. Of those that did, the majority focused on lung cancer. A recent monograph from the IARC identified 17 case-control studies exploring the association between exposure to cooking emissions and lung cancer, and all were conducted exclusively in the Chinese population [131]. Among these 17 studies, only four allowed the cookingrelated effects to be distinguished from those related to fuels [151-154]. In a group of nonsmoking females in Hong Kong, Yu et al. [152] found an escalating dose-response relationship 
between cumulative exposure (frequency and duration, in dish-years) and lung cancer risk, with a relative risk of $\sim 3$ for 101-150 and 150-200 dish-yrs exposure, and $>8$ for $>200$ dishyrs (referent exposure being $\leqslant 50$ dish-yrs). In the two studies from Shanghai, those females who stir fried most frequently were 2.6 times [154] and 2.3 times [155] as likely to have lung cancer compared with those who stir fried least often. Similarly, a study in Gansu, China reported a relative risk of 2.2 [153]. These findings might explain the observed high nonsmoking lung cancer incidence in Chinese females, which could be attributed to their high cumulative exposure to cooking emissions. However, confounding by cooking fuel could not be ruled out because of the history of using biomass or solid fuels in the study populations in the latter three studies. In addition, recall and other forms of bias that are found in case-control studies could be operating, and contributing to the positive findings in some of these studies. Therefore, the causal relationship has not yet been totally confirmed.

There are few data on respiratory diseases other than lung cancer and none was derived from developing countries. A survey of 239 kitchen workers from 67 restaurants found a four- and two-fold increase in risk of dyspnoea for females and males, respectively, compared with controls [156]. However, the results could have been confounded by combustion products, although relatively clean fuel (gas) was used in these restaurants. Assessing the possibility of acute responses, the lung function of 12 healthy volunteers were monitored over a 24-h period with and without exposure to cooking fumes for 2 and $4 \mathrm{~h}$ but found no significant changes on spirometry [156].

\section{Burning of incense sticks}

Incense is regularly burnt in homes and offices for religious or ceremonial rituals and fragrance, particularly in developing countries. Incense is available in various forms, including sticks, joss sticks, cones, coils, powder, rope, rocks/charcoal and smudge bundles. The substances widely used to produce incense are resins (such as frankincense and myrrh), spices, aromatic wood and bark, herb seeds, roots, flowers, essential oils, and synthetic substitute chemicals used in the perfume industry [157]. Burning of incense releases different air pollutants, such as PM, VOCs, carbonyl compounds, carbon monoxide, nitrogen oxides, methane, nonmethane hydrocarbons, organic carbon, elemental carbon and inorganic ions (chloride, nitrate, sulfate, sodium, ammonium and potassium ions), depending on the types of incense sticks and aroma

\section{TABLE 3 Research priorities on health effects of, exposure to and interventions for solid fuel smoke}

\begin{tabular}{|c|c|}
\hline Research priorities & Types of studies \\
\hline \multicolumn{2}{|l|}{ Health effects } \\
\hline \multirow{2}{*}{ Basic studies } & Comparative studies on exposure to solid fuel smoke, tobacco smoke, passive smoking and traffic pollutions \\
\hline & Studies on different types of health outcomes associated with exposure to solid fuel smoke but with little evidence \\
\hline \multirow[t]{4}{*}{ Epidemiological studies } & Relationship between exposure and health outcomes \\
\hline & Dose-response curve of health effects \\
\hline & Studies on toxicity of fuel types \\
\hline & Studies on health effects of other contributors to indoor air pollution (oil mist, deep frying, mosquito coil, etc.) \\
\hline \multirow[t]{3}{*}{ Clinical } & Mechanisms of health outcomes related to solid fuel smoke \\
\hline & Characterisation and early diagnosis of health outcomes \\
\hline & Histopathological differences between inhalation of biomass and tobacco smoke \\
\hline \multirow{2}{*}{ Measurements } & Modelling of personal exposure to better estimate the exposure data \\
\hline & Monitoring of intervention of improved cooking stoves in terms of exposure and their performance in the long term \\
\hline Equipment & $\begin{array}{l}\text { Research and development on types of equipment, such as cost, size, weight, power supply and resistance to extreme conditions for } \\
\text { developing countries }\end{array}$ \\
\hline \multicolumn{2}{|r|}{ 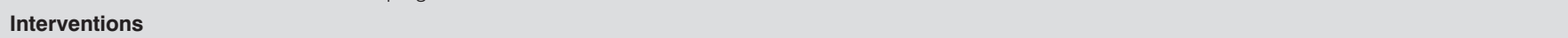 } \\
\hline \multirow[t]{2}{*}{ Improved cooking stoves } & Types of stoves (multiple stoves, multiple fuel scenarios, multiple types of food cooked and different cooking practices) \\
\hline & New biomass stove technology, better combustion and efficiency, and less pollutants emissions \\
\hline \multirow[t]{3}{*}{ Social intervention } & Impact of massive educational programmes on raising the awareness of health effects of exposure to biomass smoke \\
\hline & Acceptance of health interventions/health promotions \\
\hline & Resistance to stove/health intervention programmes \\
\hline Fuel types & Research on inexpensive but cleaner fuel types or source of heat such as production of briquettes and charcoal from agricultural wastes \\
\hline Effects & Impact of improved cooking stoves programmes on the health outcomes \\
\hline
\end{tabular}

Adapted from [20] with permission from the publisher. 
used, the concentration being much higher during the peak burning time of incense sticks [157-159]. The types of compounds present in the smoke released after burning incense suggest that they can cause a number of acute and chronic health effects. Although a number of studies has suggested that smoke released from burning can cause respiratory health effects [160, 161], lung cancer [162-164] and dermatological allergic reactions, and could be mutagenic and or genotoxic [165-167], the evidence is inconsistent, with some studies finding inverse relationships for lung cancer [168, 169] and COPD [66].

\section{Burning of mosquito coils}

Annually, 45-50 billion mosquito coils are used by $\sim 2$ billion people worldwide [170], particularly in rural and semirural communities of developing countries, to prevent mosquito bites. LIU et al. [171] estimated that burning a mosquito coil can release a mass concentration of PM2.5 equivalent to burning of 75-137 cigarettes, depending upon the types of base material used to make the mosquito coil, and release formaldehyde equivalent to 51 cigarettes. The smoke released from burning mosquito coil contains some carcinogenic PAHs, including $\mathrm{BaP}$, benzo[a]anthracene, benzo[b]fluoranthene, benzo[k]fluoranthene, dibenzo[a,h]anthracene and indeno[1,2,3-cd]pyrene $[171,172]$. People in developing countries tend to burn mosquito coils during the summer nights and are therefore regularly exposed to the smokes released for about 6-8 h daily. Inhalation of the smoke has been reported to cause breathing difficulties, eye irritation, bronchial irritation, itching, cough and asthma [171, 173, 174].

\section{CONCLUSION}

The available evidence suggests that, despite heterogeneity among published studies, there is sufficient evidence and consistency among published studies to conclude that exposure to solid fuel smoke is a risk factor to COPD in adults and pneumonia in children, particularly those $<5$ yrs of age. Although the field has been hampered by methodological weaknesses, such as exposure not being measured directly and inadequate accounting of possible confounding factors, the overall data are sufficient to be sure that the effects size for COPD is around a three-fold risk for those exposed and around a two-fold risk for ALRI in children.

The available evidence also suggests that exposure to coal smoke is a risk factor to lung cancer whereas the evidence from biomass smoke exposure on lung cancer is not conclusive. As for asthma, there remains uncertainty as to whether biomass smoke does increase the risk of developing asthma in childhood and tighter methodological studies are needed to determine any true causal association. While there is limited information suggesting that deep frying, and using incense and mosquito coils are risk factors for respiratory problems, these risk factors should be regarded only as suggestive at this stage and need to be explored further (table 3).

\section{STATEMENT OF INTEREST}

None declared.

\section{REFERENCES}

1 Rehfuess E. Fuel for Life - Household Energy and Health. Geneva, World Health Organisation, 2006.
2 Rehfuess EA, Bruce NG, Smith KR. Solid fuel use: health effect. In: Nriagu JO, ed. Encyclopedia of Environmental Health. Elsevier, Burlington, 2011; pp. 150-161.

3 International Energy Agency. World Energy Outlook 2010. Paris, International Energy Agency, 2010.

4 Naeher LP, Leaderer BP, Smith KR. Particulate matter and carbon monoxide in highland Guatemala: indoor and outdoor levels from traditional and improved wood stoves and gas stoves. Indoor Air 2000; 10: 200-205.

5 Ezzati M, Kammen D. Indoor air pollution from biomass combustion and acute respiratory infections in Kenya: an exposure-response study. Lancet 2001; 358: 619-624.

6 Begum BA, Paul SK, Dildar Hossain M, et al. Indoor air pollution from particulate matter emissions in different households in rural areas of Bangladesh. Building Environ 2009; 44: 898-903.

7 Begum BA, Biswas SK, Hopke PK. Temporal variations and spatial distribution of ambient PM2.2 and PM10 concentrations in Dhaka., Bangladesh. Sci Total Environ 2006; 358: 36-45.

8 United Nations Development Programme. UNDP-WHO report on energy access in developing countries: review of LDCs \& SSAs. http://content.undp.org/go/newsroom/publications/ environment-energy/www-ee-library/sustainable-energy/undpwho-report-on-energy-access-in-developing-countries-review-ofldcs---ssas.en Date last accessed: May 23, 2011. Date last updated: November 23, 2009.

9 International Energy Agency. World Energy Outlook 2009. Paris, Organization for Economic Co-operation and Development/ International Energy Agency, 2009.

10 Sullivan K, Barnes D. Energy Policies and Multitopic Household Surveys: Guidelines for Questionnaire Design in Living Standards Measurement Studies - Working Paper No. 90. Washinton, The World Bank, 2006.

11 Naeher LP, Brauer M, Lipsett M, et al. Woodsmoke health effects: a review. Inhal Toxicol 2007; 19: 67-106.

12 Ando M, Tadano M, Asanuma S, et al. Health effects of indoor fluoride pollution from coal burning in China. Environ Health Perspect 1998; 106: 239-244.

13 Conde FJ, Ayala JH, Afonso AM, et al. Emissions of polycyclic aromatic hydrocarbons from combustion of agricultural and sylvicultural debris. Atmos Environ 2005; 39: 6654-6663.

14 Jenkins BM, Baxter LL, Miles TR. Combustion properties of biomass. Fuel Processing Technology 1998; 54: 17-46.

15 Suarez-Garcia F, Martinez-Alonso A, Fernandez Llorente M, et al. Inorganic matter characterization in vegetable biomass feedstocks. Fuel 2002; 81: 1161-1169.

16 Tesfaigzi Y, Singh SP, Foster JE, et al. Health effects of subchronic exposure to low levels of wood smoke in rats. Toxicol Sci 2002; 65: 115-125.

17 Pandey AK, Bajpayee M, Parmar D, et al. DNA damage in lymphocytes of rural Indian women exposed to biomass fuel smoke as assessed by the Comet assay. Environ Mol Mutagen 2005; 45: 435-441.

18 Rao CM, Qin C, Robison WG Jr, et al. Effect of smoke condensate on the physiological integrity and morphology of organ cultured rat lenses. Curr Eye Res 1995; 14: 295-301.

19 Mudway I, Duggan S, Venkataraman C, et al. Combustion of dried animal dung as biofuel results in the generation of highly redox active fine particulates. Particle Fibre Toxicol 2005; 2: 6 .

20 Torres-Duque C, Maldonado D, Perez-Padilla R, et al. Biomass fuels and respiratory diseases: a review of the evidence. Proc Am Thorac Soc 2008; 5: 577-590.

21 Tunnicliffe WS, Burge PS, Ayres JG. Effect of domestic concentrations of nitrogen dioxide on airway responses to inhaled allergen in asthmatic patients. Lancet 1994; 344: 1733-1736.

22 Ray MR, Mukherjee S, Roychoudhury S, et al. Platelet activation., upregulation of CD11b/ CD18 expression on leukocytes and increase in circulating leukocyte-platelet aggregates in Indian 
women chronically exposed to biomass smoke. Hum Exp Toxicol 2006; 25: 627-635.

23 Chuang KJ, Chan CC, Su TC, et al. The effect of urban air pollution on inflammation, oxidative stress, coagulation, and autonomic dysfunction in young adults. Am J Respir Crit Care Med 2007; 176: 370-376.

24 Barregard L, Sallsten G, Gustafson P, et al. Experimental exposure to wood-smoke particles in healthy humans: effects on markers of inflammation, coagulation, and lipid peroxidation. Inhal Toxicol 2006; 18: 845-853.

25 Semple S, Devakumar D, Fullerton DG, et al. Airborne endotoxin concentrations in homes burning biomass fuel. Environ Health Perspect 2010; 118: 988-991.

26 Gilchrist MJ, Greko C, Wallinga DB, et al. The potential role of concentrated animal feeding operations in infectious disease epidemics and antibiotic resistance. Environ Health Perspect 2007; 115: 313-316.

27 Heederik D, Sigsgaard T, Thorne PS, et al. Health effects of airborne exposures from concentrated animal feeding operations. Environ Health Perspect 2007; 115: 298-302.

28 Thorne PS, Kulhankova K, Yin M, et al. Endotoxin exposure is a risk factor for asthma: the national survey of endotoxin in United States housing. Am J Respir Crit Care Med 2005; 172: 1371-1377.

29 Heederik D, Douwes J. Towards an occupational exposure limit for endotoxin? Ann Agric Environ Med 1997; 4: 17-19.

30 Bruce NG, Rehfuess EA, Smith KR. Household Energy Solutions in Developing Countries. In: Nriagu JO, ed. Encyclopedia of Environmental Health. Burlington, Elsevier, 2011; p. 6275.

31 Kurmi OP, Semple S, Steiner M, et al. Particulate matter exposure during domestic work in Nepal. Ann Occup Hyg 2008; 52 509-517.

32 Park E, Lee K. Particulate exposure and size distribution from wood burning stoves in Costa Rica. Indoor Air 2003; 13: 253-259.

33 Regalado J, Perez-Padilla R, Sansores R, et al. The effect of biomass burning on respiratory symptoms and lung function in rural Mexican women. Am J Respir Crit Care Med 2006; 174 901-905

34 Shrestha IL, Shrestha SL. Indoor air pollution from biomass fuels and respiratory health of the exposed population in Nepalese households. Int J Occup Environ Health 2005; 11: 150-160.

35 Collings DA, Sithole SD, Martin KS. Indoor woodsmoke pollution causing lower respiratory disease in children. Trop Doct 1990; 20: 151-155.

36 Jiang R, Bell ML. A comparison of particulate matter from biomass-burning rural and non-biomass-burning urban households in northeastern China. Environ Health Perspect 2008; 116: 907-914.

37 World Health Organization. WHO Air Quality Guidelines for Particulate Matter, Ozone, Nitrogen Dioxide and Sulfur Dioxide. http://whqlibdoc.who.int/hq/2006/WHO_SDE_PHE_OEH_06. 02_eng.pdf Date last accessed: August 20, 2007. Date last updated: 2005.

38 Jones NC, Thornton CA, Mark D, et al. Indoor/outdoor relationships of particulate matter in domestic homes with roadside., urban and rural locations. Atmos Environ 2000; 34: 2603-2612

39 Williams DL, Breysse PN, McCormack MC, et al. Airborne cow allergen, ammonia and particulate matter at homes vary with distance to industrial scale dairy operations: an exposure assessment. Environ Health 2011; 10: 72.

40 Bruce N, McCracken J, Albalak R, et al. Impact of improved stoves, house construction and child location on levels of indoor air pollution exposure in young Guatemalan children. J Expo Anal Environ Epidemiol, 14: Suppl. 1, S26-S33.

41 Demirbas A. Combustion characteristics of different biomass fuels. Prog Energ Combust 2004; 30: 219-230.
42 Raub J. Environmental Health Criteria 213: Carbon Monoxide 2nd Edn. http://whqlibdoc.who.int/ehc/WHO_EHC_213.pdf Date last accessed: May 24, 2011. Date last updated: November 30, 2004.

43 Roehr B. Environmentalists seek to set research agenda on indoor air pollution. BMJ 2011; 342.

44 World Health Organisation. Global Health Risks: Mortality and Burden of Disease Attributable to Selected Major Risks. www. who.int/healthinfo/global_burden_disease/GlobalHealthRisks_ report_full.pdf Date last accessed: May 26, 2011. Date last updated: 2009

45 Kurmi OP, Semple S, Simkhada P, et al. COPD and chronic bronchitis risk of indoor air pollution from solid fuel: a systematic review and meta-analysis. Thorax 2010; 65: 221-228.

46 Dherani M, Pope D, Mascarenhas M, et al. Indoor air pollution from unprocessed solid fuel use and pneumonia risk in children aged under five years: a systematic review and meta-analysis. Bull World Health Organ 2008; 86: 390C-398C.

47 Hosgood HD, Boffetta P, Greenland S, et al. In-home coal and wood use and lung cancer risk: a pooled-analysis of the International Lung Cancer Consortium. Environ Health Perspect 2010; 118: 1743-1747.

48 Lin HH, Ezzati M, Murray M. Tobacco smoke, indoor air pollution and tuberculosis: a systematic review and metaanalysis. PLoS Med 2007; 4: e20.

49 Pokhrel AK, Smith KR, Khalakdina A, et al. Case-control study of indoor cooking smoke exposure and cataract in Nepal and India. Int J Epidemiol 2005; 34: 702-708.

50 Mishra V, Dai X, Smith KR, et al. Maternal exposure to biomass smoke and reduced birth weight in Zimbabwe. Ann Epidemiol 2004; 14: 740-747.

51 Romieu I, Riojas-Rodriguez H, Marron-Mares AT, et al Improved biomass stove intervention in rural Mexico: impact on the respiratory health of women. Am J Respir Crit Care Med 2009; 180: 649-656.

52 Kurmi OP, Gaihre S, Semple S, et al. Acute exposure to biomass smoke causes oxygen desaturation in adult women. Thorax 2011 66: 724-725.

53 Bruce N, Weber M, Arana B, et al. Pneumonia case-finding in the RESPIRE Guatemala indoor air pollution trial: standardizing methods for resource-poor settings. Bull World Health Organ 2007; 85: 535-544.

54 World Health Organization. The Global Burden of Disease: Update 2004. Geneva, World Health Organization, 2008.

55 World Health Organization. Indoor Air Pollution and Health. www.who.int/mediacentre/factsheets/fs292/en/ Date last accessed: October 14, 2009. Date last updated: September 2011.

56 Bruce N, Perez-Padilla R, Albalak R. The Health Effects of Indoor Air Pollution Exposure in Developing Countries. Geneva, World Health Organization, 2002.

57 Pandey MR. Prevalence of chronic bronchitis in a rural community of the Hill Region of Nepal. Thorax 1984; 39: 331-336.

58 Smith KR, Samet JM, Romieu I, et al. Indoor air pollution in developing countries and acute lower respiratory infections in children. Thorax 2000; 55: 518-532.

59 Barregard L, Saellsten G, Andersson L, et al. Experimental exposure to wood smoke: effects on airway inflammation and oxidative stress. Occup Environ Med 2008; 65: 319-324.

60 Miljevic B, Heringa MF, Keller A, et al. Oxidative potential of logwood and pellet burning particles assessed by a novel profluorescent nitroxide probe. Environ Sci Technol 2010; 44: 6601-6607.

61 Barnes PJ. Mechanisms in COPD: differences from asthma. Chest 2000; 117: Suppl. 2, 10S-14S.

62 Ceylan E, Kocyigit A, Gencer M, et al. Increased DNA damage in patients with chronic obstructive pulmonary disease who had 
once smoked or been exposed to biomass. Respir Med 2006; 100: 1270-1276.

63 Rivera RM, Cosio MG, Ghezzo H, et al. Comparison of lung morphology in COPD secondary to cigarette and biomass smoke. Int J Tuberc Lung Dis 2008; 12: 972-977.

64 Moran-Mendoza O, Perez-Padilla JR, Salazar-Flores M, et al. Wood smoke-associated lung disease: a clinical, functional, radiological and pathological description. Int J Tuberc Lung Dis 2008; 12: 1092-1098.

65 Kiraz K, Kart L, Demir R, et al. Chronic pulmonary disease in rural women exposed to biomass fumes. Clin Invest Med 2003; 26: 243-248.

66 Døssing M, Khan J, al-Rabiah F. Risk factors for chronic obstructive lung disease in Saudi Arabia. Respir Med 1994; 88: 519-522.

67 Orozco-Levi M, Garcia-Aymerich J, Villar J, et al. Wood smoke exposure and risk of chronic obstructive pulmonary disease. Eur Respir J 2006; 27: 542-546.

68 Dennis RJ, Maldonado D, Norman S, et al. Woodsmoke exposure and risk for obstructive airways disease among women. Chest 1996; 109: 115-119.

69 Liu S, Zhou Y, Wang X, et al. Biomass fuels are the probable risk factor for chronic obstructive pulmonary disease in rural South China. Thorax 2007; 62: 889-897.

70 Ekici A, Ekici M, Kurtipek E, et al. Obstructive airway diseases in women exposed to biomass smoke. Environ Res 2005; 99: 93-98.

71 Caballero A, Torres-Duque CA, Jaramillo C, et al. Prevalence of COPD in five Colombian cities situated at low, medium, and high altitude (PREPOCOL study). Chest 2008; 133: 343-349.

72 Zhong N, Wang C, Yao W, et al. Prevalence of chronic obstructive pulmonary disease in China: a large, populationbased survey. Am J Respir Crit Care Med 2007; 176: 753-760.

73 Sezer H, Akkurt I, Guler N, et al. A case-control study on the effect of exposure to different substances on the development of COPD. Ann Epidemiol 2006; 16: 59-62.

74 Chapman RS, He X, Blair AE, et al. Improvement in household stoves and risk of chronic obstructive pulmonary disease in Xuanwei, China: retrospective cohort study. BMJ 2005; 331: 1050.

$75 \mathrm{Xu} \mathrm{F}$, Yin X, Shen $\mathrm{H}$, et al. Better understanding the influence of cigarette smoking and indoor air pollution on chronic obstructive pulmonary disease: a case-control study in Mainland China. Respirology 2007; 12: 891-897.

76 Pandey MR. Domestic smoke pollution and chronic bronchitis in a rural community of the Hill Region of Nepal. Thorax 1984; 39: 337-339.

77 Dutt D, Srinivasa DK, Rotti SB, et al. Effect of indoor air pollution on the respiratory system of women using different fuels for cooking in an urban slum of Pondicherry. Natl Med J India 1996; 9: 113-117.

78 Pérez-Padilla R, Regalado J, Vedal S, et al. Exposure to biomass smoke and chronic airway disease in Mexican women. A casecontrol study. Am J Respir Crit Care Med 1996; 154: 701-706.

79 Uzun K, Ozbay B, Ceylan E, et al. Prevalence of chronic bronchitis-asthma symptoms in biomass fuel exposed females. Environ Health Prev Med 2003; 8: 13-17.

80 Akhtar T, Ullah Z, Khan MH, et al. Chronic bronchitis in women using solid biomass fuel in rural Peshawar, Pakistan. Chest 2007; 132: $1472-1475$.

81 Golshan M, Faghihi M, Marandi MM. Indoor women jobs and pulmonary risks in rural areas of Isfahan, Iran, 2000. Respir Med 2002; 96: 382-388.

82 Albalak R, Frisancho AR, Keeler GJ. Domestic biomass fuel combustion and chronic bronchitis in two rural Bolivian villages. Thorax 1999; 54: 1004-1008.

83 Qureshi KA. Domestic smoke pollution and prevalence of chronic bronchitis/asthma in a rural area of Kashmir. Indian J Chest Dis Allied Sci 1994; 36: 61-72.
84 Cetinkaya F, Gülmez I, Aydin T, et al. Prevalence of chronic bronchitis and associated risk factors in a rural area of Kayseri, Central Anatolia, Turkey. Monaldi Arch Chest Dis 2000; 55: 189-193.

85 Menezes AM, Victora CG, Rigatto M. Prevalence and risk factors for chronic bronchitis in Pelotas, RS, Brazil: a population-based study. Thorax 1994; 49: 1217-1221.

86 Behera D, Jindal SK. Respiratory symptoms in Indian women using domestic cooking fuels. Chest 1991; 100: 385-388.

87 Po JY, FitzGerald JM, Carlsten C. Respiratory disease associated with solid biomass fuel exposure in rural women and children systematic review and meta-analysis. Thorax 2011; 66: 232-239.

88 Kurmi OP, Devereux GS, Smith WC, et al. Reduced lung function due to biomass smoke exposure in young adults in rural Nepal. Eur Respir J 2012; [Epub ahead of print DOI: 10.1183/ 09031936.0220511].

89 Worldwide variation in prevalence of symptoms of asthma, allergic rhinoconjunctivitis, and atopic eczema: ISAAC. The International Study of Asthma and Allergies in Childhood (ISAAC) Steering Committee. Lancet 1998; 351: 1225-1232.

90 Braun-Fahrländer C, Riedler J, Herz U, et al. Environmental exposure to endotoxin and its relation to asthma in school-age children. N Engl J Med 2002; 347: 869-877.

91 Dab W, Medina S, Quenel P, et al. Short term respiratory health effects of ambient air pollution: results of the APHEA project in Paris. J Epidemiol Community Health 1996; 50: Suppl. 1, s42-s46.

92 Lipsett M, Hurley S, Ostro B. Air pollution and emergency room visits for asthma in Santa Clara County, California. Environ Health Perspect 1997; 105: 216-222.

93 Whittemore AS, Korn EL. Asthma and air pollution in the Los Angeles area. Am J Public Health 1980; 70: 687-696.

94 Samuelsen M, Nygaard UC, Lovik M. Allergy adjuvant effect of particles from wood smoke and road traffic. Toxicology 2008; 246: 124-131.

95 Mohamed N, Ng'ang'a L, Odhiambo J, et al. Home environment and asthma in Kenyan schoolchildren: a case-control study. Thorax 1995; 50: 74-78.

96 Azizi BH, Zulkifli HI, Kasim S. Indoor air pollution and asthma in hospitalized children in a tropical environment. J Asthma 1995; 32: 413-418.

97 Melsom T, Brinch L, Hessen JO, et al. Asthma and indoor environment in Nepal. Thorax 2001; 56: 477-481.

98 Mishra V. Effect of indoor air pollution from biomass combustion on prevalence of asthma in the elderly. Environ Health Perspect 2003; 111: 71-78.

99 Schei MA, Hessen JO, Smith KR, et al. Childhood asthma and indoor woodsmoke from cooking in Guatemala. I Expo Anal Environ Epidemiol 2004; 14: Suppl. 1, S110-S117.

100 Monto AS, Lehmann D. Acute respiratory infections (ARI) in children: prospects for prevention. Vaccine 1998; 16: 1582-1588.

101 World Health Organization. Global Burden of Disease: 2004 Update. Geneva, World Health Organization, 2008.

102 Reynolds HY. Defense mechanisms against infections. Curr Opin Pulm Med 1999; 5: 136-142.

103 Ezzati M, Kammen DM. Quantifying the effects of exposure to indoor air pollution from biomass combustion on acute respiratory infections in developing countries. Environ Health Perspect 2001; 109: 481-488.

104 Pandey MR, Neupane RP, Gautam A, et al. Domestic smoke pollution and acute respiratory infections in a rural community of the hill region of Nepal. Environ Int 1989; 15: 337-340.

105 Johnson AW, Aderele WI. The association of household pollutants and socio-economic risk factors with the short-term outcome of acute lower respiratory infections in hospitalized pre-school Nigerian children. Ann Trop Paediatr 1992; 12 421-432. 
106 Mishra V. Indoor air pollution from biomass combustion and acute respiratory illness in preschool age children in Zimbabwe. Int J Epidemiol 2003; 32: 847-853.

107 Armstrong JR, Campbell H. Indoor air pollution exposure and lower respiratory infections in young Gambian children. Int $J$ Epidemiol 1991; 20: 424-429.

108 Dherani M, Pope D, Mascarenhas M, et al. Indoor air pollution from unprocessed solid fuel use and pneumonia risk in children aged under five years: a systematic review and meta-analysis. Bull World Health Organ 2008; 86: 390-398.

109 Pokhrel AK, Bates MN, Verma SC, et al. Tuberculosis and indoor biomass and kerosene use in Nepal: a case-control study. Environ Health Perspect 2010; 118: 558-564.

110 Crampin AC, Glynn JR, Floyd S, et al. Tuberculosis and gender: exploring the patterns in a case control study in Malawi. Int Tuberc Lung Dis 2004; 8: 194-203.

111 Mishra VK, Retherford RD, Smith KR. Biomass cooking fuels and prevalence of tuberculosis in India. Int J Infect Dis 1999; 3: 119-129.

112 Leung CC, Li T, Lam TH, et al. Smoking and tuberculosis among the elderly in Hong Kong. Am J Respir Crit Care Med 2004; 170: 1027-1033.

113 Shetty N, Shemko M, Vaz M, et al. An epidemiological evaluation of risk factors for tuberculosis in South India: a matched case control study. Int I Tuberc Lung Dis 2006; 10: 80-86.

114 Jick SS, Lieberman ES, Rahman MU, et al. Glucocorticoid use, other associated factors, and the risk of tuberculosis. Arthritis Rheum 2006; 55: 19-26.

115 Lienhardt C, Fielding K, Sillah JS, et al. Investigation of the risk factors for tuberculosis: a case-control study in three countries in West Africa. Int J Epidemiol 2005; 34: 914-923.

116 Wang GJ, Sleigh A, Zhou G, et al. [Nonbiologic risk factors of pulmonary tuberculosis among adults in Henan: a case-control study]. Zhonghua Liu Xing Bing Xue Za Zhi 2005; 26: 92-96.

117 Tipayamongkholgul M, Podhipak A, Chearskul S, et al. Factors associated with the development of tuberculosis in BCG immunized children. Southeast Asian J Trop Med Public Health 2005; 36: 145-150.

118 Altet MN, Alcaide J, Plans P, et al. Passive smoking and risk of pulmonary tuberculosis in children immediately following infection. A case-control study. Tuber Lung Dis 1996; 77: 537-544.

119 Houtmeyers E, Gosselink R, Gayan-Ramirez G, et al. Regulation of mucociliary clearance in health and disease. Eur Respir J 1999; 13: 1177-1188.

120 Beck BD, Brain JD, Bohannon DE. An in vivo hamster bioassay to assess the toxicity of particulates for the lungs. Toxicol Appl Pharmacol 1982; 66: 9-29.

121 Fick RB Jr, Paul ES, Merrill WW, et al. Alterations in the antibacterial properties of rabbit pulmonary macrophages exposed to wood smoke. Am Rev Respir Dis 1984; 129: 76-81.

122 Gninafon M, Ade G, Aït-Khaled N, et al. Exposure to combustion of solid fuel and tuberculosis: a matched case-control study. Eur Respir J 2011; 38: 132-138.

123 Kan X, Chiang CY, Enarson DA, et al. Indoor solid fuel use and tuberculosis in China: a matched case-control study. BMC Public Health 2011; 11: 498.

124 Lakshmi PV, Virdi NK, Thakur JS, et al. Biomass fuel and risk of tuberculosis: a case-control study from Northern India. J Epidemiol Community Health 2012; 66: 457-461.

125 Kolappan C, Subramani R. Association between biomass fuel and pulmonary tuberculosis: a nested case-control study. Thorax 2009; 64: 705-708.

126 Perez-Padilla R, Perez-Guzman C, Baez-Saldana R, et al. Cooking with biomass stoves and tuberculosis: a case control study. Int $J$ Tuberc Lung Dis 2001; 5: 441-447.
127 Mishra VK, Retherford RD, Smith KR. Cooking with biomass fuels increases the risk of tuberculosis. Natl Fam Health Surv Bull 1999; 13: 1-4.

128 Gupta BN, Mathur N, Mahendra PN, et al. A study of household environmental risk factors pertaining to respiratory diseases. Energy Environment Monitor 1997; 1: 61-67.

129 Parkin DM, Bray F, Ferlay J, et al. Global cancer statistics, 2002. CA Cancer I Clin 2005; 55: 74-108.

130 Sun S, Schiller JH, Gazdar AF. Lung cancer in never smokers - a different disease. Nat Rev Cancer 2007; 7: 778-790.

131 IARC Working Group on the Evaluation of Carcinogenic Risks to Humans. Household use of solid fuels and high-temperature frying. IARC Monogr Eval Carcinog Risks Hum 2010; 95: 1-430.

132 Peto R, Darby S, Deo H, et al. Smoking, smoking cessation, and lung cancer in the UK since 1950: combination of national statistics with two case-control studies. BMJ 2000; 321: 323-329.

133 Hirayama T. Non-smoking wives of heavy smokers have a higher risk of lung cancer: a study from Japan. Br Med J (Clin Res Ed) 1981; 282: 183-185.

134 Whitwell F, Newhouse ML, Bennett DR. A study of the histological cell types of lung cancer in workers suffering from asbestosis in the United Kingdom. Br J Ind Med 1974; 31: 298-303.

135 Tang DL, Rundle A, Warburton D, et al. Associations between both genetic and environmental biomarkers and lung cancer: evidence of a greater risk of lung cancer in women smokers. Carcinogenesis 1998; 19: 1949-1953.

136 Zhao Y, Wang S, Aunan K, et al. Air pollution and lung cancer risks in China - a meta-analysis. Sci Total Environ 2006; 366: 500-513.

137 Nakachi K, Imai K, Hayashi S, et al. Genetic susceptibility to squamous cell carcinoma of the lung in relation to cigarette smoking dose. Cancer Res 1991; 51: 5177-5180.

138 Kusano C, Gotoda T, Khor CJ, et al. Changing trends in the proportion of adenocarcinoma of the esophagogastric junction in a large tertiary referral center in Japan. J Gastroenterol Hepatol 2008; 23: 1662-1665.

139 Vainiotalo S, Matveinen K. Cooking fumes as a hygienic problem in the food and catering industries. Am Indust Hygiene Assoc J 1993; 54: 376-382.

140 Zhang Q, Gangupomu RH, Ramirez D, et al. Measurement of ultrafine particles and other air pollutants emitted by cooking activities. Int J Environ Res Public Health 2010; 7: 1744-1759.

141 Huang Y, Ho SS, Ho KF, et al. Characteristics and health impacts of VOCs and carbonyls associated with residential cooking activities in Hong Kong. J Hazard Mater 2011; 186: 344-351.

142 Chen BH, Chen YC. Formation of polycyclic aromatic hydrocarbons in the smoke from heated model lipids and food lipids. J Agric Food Chem 2001; 49: 5238-5243.

143 Cross AJ, Sinha R. Meat-related mutagens/carcinogens in the etiology of colorectal cancer. Environ Mol Mutagen 2004; 44: 44-55.

144 Sjaastad AK, Svendsen K. Exposure to mutagenic aldehydes and particulate matter during panfrying of beefsteak with margarine, rapeseed oil, olive oil or soybean oil. Ann Occup Hyg 2008; 52: 739-745.

145 Fullana A, Carbonell-Barrachina AA, Sidhu S. Comparison of volatile aldehydes present in the cooking fumes of extra virgin olive, olive, and canola oils. J Agric Food Chem 2004; 52: 5207-5214.

146 Chiang TA, Wu PF, Wang LF, et al. Mutagenicity and polycyclic aromatic hydrocarbon content of fumes from heated cooking oils produced in Taiwan. Mutat Res 1997; 381: 157-161.

147 Chiang TA, Pei-Fen W, Ying LS, et al. Mutagenicity and aromatic amine content of fumes from heated cooking oils produced in Taiwan. Food Chem Toxicol 1999; 37: 125-134.

$148 \mathrm{Du} Y X$, Cha $Q$, Chen XW, et al. An epidemiological study of risk factors for lung cancer in Guangzhou, China. Lung Cancer 1996; 14: Suppl. 1, S9-S37. 
149 Li CT, Lin YC, Lee WJ, et al. Emission of polycyclic aromatic hydrocarbons and their carcinogenic potencies from cooking sources to the urban atmosphere. Environ Health Perspect 2003; 111: $483-487$.

150 Wei See S, Karthikeyan S, Balasubramanian R. Health risk assessment of occupational exposure to particulate-phase polycyclic aromatic hydrocarbons associated with Chinese, Malay and Indian cooking. J Environ Monit 2006; 8: 369-376.

151 Zhong L, Goldberg MS, Gao YT, et al. A case-control study of lung cancer and environmental tobacco smoke among nonsmoking women living in Shanghai, China. Cancer Causes Control 1999; 10: 607-616.

152 Yu IT, Chiu YL, Au JS, et al. Dose-response relationship between cooking fumes exposures and lung cancer among Chinese nonsmoking women. Cancer Res 2006; 66: 4961-4967.

153 Metayer C, Wang Z, Kleinerman RA, et al. Cooking oil fumes and risk of lung cancer in women in rural Gansu, China. Lung Cancer 2002; 35: 111-117.

154 Gao YT, Blot WJ, Zheng W, et al. Lung cancer among Chinese women. Int J Cancer 1987; 40: 604-609.

155 Svendsen K, Sjaastad AK, Sivertsen I. Respiratory symptoms in kitchen workers. Am J Ind Med 2003; 43: 436-439.

156 Svedahl S, Svendsen K, Qvenild T, et al. Short term exposure to cooking fumes and pulmonary function. J Occup Med Toxicol 2009; 4: 9 .

157 Jetter JJ, Guo Z, McBrian JA, et al. Characterization of emissions from burning incense. Sci Total Environ 2002; 295: 51-67.

158 Wang B, Lee SC, Ho KF, et al. Characteristics of emissions of air pollutants from burning of incense in temples, Hong Kong. Sci Total Environ 2007; 377: 52-60.

159 Lee S-C, Wang B. Characteristics of emissions of air pollutants from burning of incense in a large environmental chamber. Atmos Environ 2004; 38: 941-951.

160 Hong CY, Ng TP, Wong ML, et al. Lifestyle and behavioural risk factors associated with asthma morbidity in adults. QJM 1994; 87: 639-645.

161 Dawod ST, Hussain AA. Childhood asthma in Qatar. Ann Allergy Asthma Immunol 1995; 75: 360-364.
162 McCredie M, Maisonneuve P, Boyle P. Perinatal and early postnatal risk factors for malignant brain tumours in New South Wales children. Int J Cancer 1994; 56: 11-15.

163 MacLennan R, Da Costa J, Day NE, et al. Risk factors for lung cancer in Singapore Chinese, a population with high female incidence rates. Int J Cancer 1977; 20: 854-860.

164 Lowengart RA, Peters JM, Cicioni C, et al. Childhood leukemia and parents' occupational and home exposures. J Natl Cancer Inst 1987; 79: 39-46.

165 Sato S, Makino R, Takahashi Y, et al. Mutagenicity of smoke condensates from joss sticks. Mutat Res 1980; 77: 31-36.

166 Rasmussen RE. Mutagenic activity of incense smoke in Salmonella typhimurium. Bull Environ Contam Toxicol 1987; 38: 827-833.

167 Chang HL, Kuo ML, Lin JM. Mutagenic activity of incense smoke in comparison to formaldehyde and acetaldehyde in Salmonella typhimurium TA102. Bull Environ Contam Toxicol 1997; 58: 394-401.

168 Koo LC, Ho JH. Diet as a confounder of the association between air pollution and female lung cancer: Hong Kong studies on exposures to environmental tobacco smoke, incense, and cooking fumes as examples. Lung Cancer 1996; 14: Suppl. 1, S47-S61.

169 Ger LP, Hsu WL, Chen KT, et al. Risk factors of lung cancer by histological category in Taiwan. Anticancer Res 1993; 13: 1491-1500.

170 Zhang L, Jiang Z, Tong J, et al. Using charcoal as base material reduces mosquito coil emissions of toxins. Indoor Air 2010; 20: 176-184.

171 Liu W, Zhang J, Hashim JH, et al. Mosquito coil emissions and health implications. Environ Health Perspect 2003; 111: 1454-1460.

172 Chen Y, Sheng G, Bi X, et al. Emission factors for carbonaceous particles and polycyclic aromatic hydrocarbons from residential coal combustion in China. Environ Sci Technol 2005; 39: 1861-1867.

173 Pauluhn J, Mohr U. Mosquito coil smoke inhalation toxicity. Part II: subchronic nose-only inhalation study in rats. J Appl Toxicol 2006; 26: 279-292.

174 Pauluhn J. Mosquito coil smoke inhalation toxicity. Part I: validation of test approach and acute inhalation toxicity. J Appl Toxicol 2006; 26: 269-278. 